\title{
Relationship between Aspects of Academic Motivation of Adolescents
}

\author{
Reena*, Bimla dhanda** and Pinki ninaniya*** \\ Department of Human Development and Family Studies I. C. College of Home Sciences \\ CCSHAU, Hisar-125004Haryana, India
}

\begin{abstract}
The present study was carried out on 300 adolescents from Panipat district of Haryana state. Academic motivation Scale by Areepattamannil (2006) was used to assess academic motivation of adolescents. . It was found that intrinsic motivation - to know was significantly positively correlated with Intrinsic motivation- toward accomplishment $\left(\mathrm{r}=0.65^{* *}\right)$, Intrinsic motivation- experience stimulation $\left(\mathrm{r}=0.46^{* *}\right)$. Intrinsic motivation- toward accomplishment was correlated with Intrinsic motivation - to know $\left(\mathrm{r}=0.65^{* *}\right)$, Intrinsic motivation- toward accomplishment $\left(\mathrm{r}=0.25^{* *}\right)$. Results revealed that there were all aspects of academic motivation were significantly correlated with each other respectively.
\end{abstract}

KEY WORDS: Academic motivation, Adolescents, Intrinsic motivation, extrinsic motivation Introduction

Adolescents need academic motivation that occurs during the transitions to middle school and high school age (Skinner et al., 2008). Motivation has been defined as the attribute that "moves" us to do or not do something. Academic motivation is multidimensional in nature, and is comprised of three global types of motivation: intrinsic motivation, extrinsic motivation, and amotivation (Deci and Ryan, 2000). Lepper et al. (2005) postulate that intrinsic and extrinsic motivation may be largely orthogonal dimensions of motivation in school, and developing both intrinsic and extrinsic motives can be adaptive for students. Within-domain interrelations among these motivation constructs were generally consistent with previous research. More important, consistent patterns of relations were observed in four different academic domains within each age group (Bong, M., 2001). Teacher support has been associated with greater school/academic engagement and motivation, as well as better academic performance Demaray and Malecki (2006).

\section{MATERIAL AND METHODS}

Present study was conducted purposively at rural government schools of the district Panipat of state Haryana. Random sampling procedure was used to select the sample. A sample of 300 hundred students studying in the age group of 13-14 years and studying in the $8^{\text {th }}$ grade. These adolescents were selected from six government schools from three Block of district Panipat. The boys and girls were included in the sample. Academic motivation Scale by Areepattamannil (2006) was used to assess the relationship between aspects of academic motivation of adolescents.

\section{RESULTS}

Correlation between aspects of academic motivation

Table 1 indicates correlation between aspects of academic motivation. It was found that intrinsic motivation - to know was significantly positively correlated with Intrinsic motivation- toward accomplishment ( $\left.\mathrm{r}=0.65^{* *}\right)$, Intrinsic motivation- experience stimulation $\left(\mathrm{r}=0.46^{* *}\right)$, Intrinsic motivation- toward accomplishment was correlated with Intrinsic motivation - to know $\left(\mathrm{r}=0.65^{* *}\right)$, Intrinsic motivation- toward accomplishment $(\mathrm{r}=0.25 * *)$.

Table: 1 Correlation between aspects of academic motivation of respondents

\begin{tabular}{|l|l|c|c|c|}
\hline $\begin{array}{l}\text { Sr. } \\
\text { No. }\end{array}$ & $\begin{array}{l}\text { Aspects of } \\
\text { Academic } \\
\text { motivation }\end{array}$ & \multicolumn{3}{|c|}{ Aspects of Academic motivation } \\
\hline & & $\begin{array}{c}\text { Intrinsic } \\
\text { motivation }- \text { to } \\
\text { know }\end{array}$ & $\begin{array}{c}\text { Intrinsic } \\
\text { motivation- } \\
\text { toward } \\
\text { accomplishment }\end{array}$ & $\begin{array}{c}\text { Intrinsic } \\
\text { motivation- } \\
\text { experience } \\
\text { stimulation }\end{array}$ \\
\hline 1. & Intrinsic & 1.00 & - & - \\
\hline
\end{tabular}


Relationship between Aspects of Academic Motivation of Adolescents

\begin{tabular}{|c|c|c|c|c|}
\hline & $\begin{array}{l}\text { motivation }- \text { to } \\
\text { know }\end{array}$ & & & \\
\hline 2. & $\begin{array}{l}\text { Intrinsic } \\
\text { motivation- } \\
\text { toward } \\
\text { accomplishment }\end{array}$ & $0.65 * *$ & 1.00 & - \\
\hline 3. & $\begin{array}{l}\text { Intrinsic } \\
\text { motivation- } \\
\text { experience } \\
\text { stimulation }\end{array}$ & $0.46^{* *}$ & $0.25 * *$ & 1.00 \\
\hline
\end{tabular}

\section{DISCUSSION}

Ahmed and Bruinsma (2006) found that academic motivation was positively related to academic achievement. Also found that the positive relationship between academic self-concept and intrinsic motivation significant. Therefore, those the students felt positive about themselves and their academic abilities were more intrinsically motivated for academic tasks. Cowdhury et al. (2007) viewed that motivation is inner drive that directs students' behavior towards the fulfilment of their goal. Result revealed that extrinsic and intrinsic motivation has positive relationship with academic motivation.

\section{RESULTS AND DISCUSSION}

Correlation between aspects of academic motivation. It was found that intrinsic motivation - to know was significantly positively correlated with Intrinsic motivation- toward accomplishment ( $\left.\mathrm{r}=0.65^{* *}\right)$, Intrinsic motivation- experience stimulation $\left(\mathrm{r}=0.46^{* *}\right)$, Ahmed and Bruinsma (2006) found that academic motivation was positively related to academic achievement. Also found that the positive relationship between academic self-concept and intrinsic motivation significant. Therefore, those the students felt positive about themselves and their academic abilities were more intrinsically motivated for academic tasks. Intrinsic motivation- toward accomplishment was correlated with Intrinsic motivation - to know $\left(\mathrm{r}=0.65^{* *}\right)$, Intrinsic motivation- toward accomplishment $\left(\mathrm{r}=0.25^{* *}\right)$. Cowdhury et al. (2007) viewed that motivation is inner drive that directs students' behavior towards the fulfilment of their goal. Result revealed that extrinsic and intrinsic motivation has positive relationship with academic motivation.

\section{REFERENCES}

[1] Ahmed, W., \& Bruinsma, M. 2006. A structural model of self-concept, autonomous motivation and academic performance in cross-cultural perspective. Electronic Journal of Research in Educational Psychology 10(4) 551-572.

[2] Bong, M. 2001. Between and within domain relations of academic motivation among middle and high school students: self efficacy, task value and achievement goals. Journal of Educational Psychology, 93( 1), 23-29

[3] Chowdhury,Mohammed S.and Shahabuddin 2007. Self efficacy, motivation and their relationship to academic performance of Bangladesh College Students.

[4] Ryan, R.M., \& Deci, E.L. 2000. Intrinsic and extrinsic motivations: classic definitions and new directions. Contemporary Educational Psychology, 25:54-67.

[5] Demary M.K and Malecki, C.K 2006. Relation between sources of perceived sports and maladjustment for student at risk.Pschology in the School 39(3), 305-316

[6] Lepper, M.R., Corpus, J.H. \& Iyengar, S.S. 2005. Intrinsic and extrinsic motivational orientations in the classroom: Age differences and academic correlates. Journal of Educational Psychology, 97(2) 184-196.

[7] Skinner, E. A., Furrer, C., Marchand, G., \& Kindermann, T. 2008. Engagement and disaffection in the classroom: Part of a larger motivational dynamic? Journal of Educational Psychology, 100: 765-781. 